\title{
Guest Editors' Foreword: \\ Proceedings of the 19th Biennial Symposium of the International Colour Vision Society. Held July 2007 Belém, Brazil
}

The 19th Symposium of the International Colour Vision Society (ICVS) was held in Belém, Brazil in July 2007. This was the first time that the Society has met in Latin America. The Amazonian region was a unique location for this inauguration due both to its situation close to a vast, largely unexplored region of nature, and resources - an inspiring challenge for scientific study-and to the quality of the vision research developing in the region.

ICVS, formerly the International Research Group for Colour Vision Deficiencies, is made up of vision scientists and clinicians with broad interests in colour vision. The topics of the Symposium reflected the range of these interests, with sessions devoted to cone receptors, colour vision in New World primates, through molecular genetics of colour vision, to colour and reality, as well as acquired colour deficiencies and clinical testing techniques. These topics are covered in the peer-reviewed papers in this issue. The Society's Symposia thus provide an outstanding opportunity to make contact and develop common interests across disciplinary boundaries.

We are grateful to the contributors and referees who made this issue possible. We thank the Editor-in-Chief, Laura J. Frishman, for the renewed opportunity to publish our Proceedings in Visual Neuroscience and the logistical support from Cambridge University Press. We also thank Conselho Nacional de Desenvolvimento Científico e Tecnológico (CNPq), Coordenação de Aperfeiçoamento de Pessoal de Ensino Superior (CAPES), Fundo Estadual de Ciência e Tecnologia (FUNTEC), International Brain Research Organization (IBRO), Universidade Federal do Pará (UFPA), Universidade de São Paulo (USP), Universidade do Estado do Pará (UEPA), Brazilian Association for Vision and Ophthalmology (BRAVO), Fundação de Amparo e Desenvolvimento da Pesquisa (FADESP), Financiadora de Estudos e Projetos (FINEP), Banco da Amazônia (BASA), Federação das Indústrias do Estado do Pará (FIEPA), UNIMED-Belém, Quality Incorporadora, and Laboratório Paulo Azevedo for financial support that made the symposium possible and permitted so many vision scientists to attend. In particular, the Society welcomes participation from young scientists; we were fortunate to have been able to provide financial support for many from outside Brazil and we were also able to welcome a considerable contingent of Brazilian students.

The next meeting of ICVS will be held in Braga, Portugal in 2009. We hope to be able to welcome a wide international spectrum of attendees; the meeting website will be available from the autumn of 2008, and can be accessed through the Society's web page (www.icvs.info). We also invite your membership of ICVS. Membership details may be obtained from Dr. Neil Parry (neil.parry@manchester.ac.uk).

Luiz Carlos de Lima Silveira Universidade Federal do Pará, Belém, Brazil

Hannah Smithson University of Durham, England, United Kingdom

Dora Fix Ventura University of São Paulo, São Paulo, Brazil

Barry B. Lee

SUNY College of Optometry, New York, USA Max Planck Institute for Biophysical Chemistry, Göttingen, Germany 


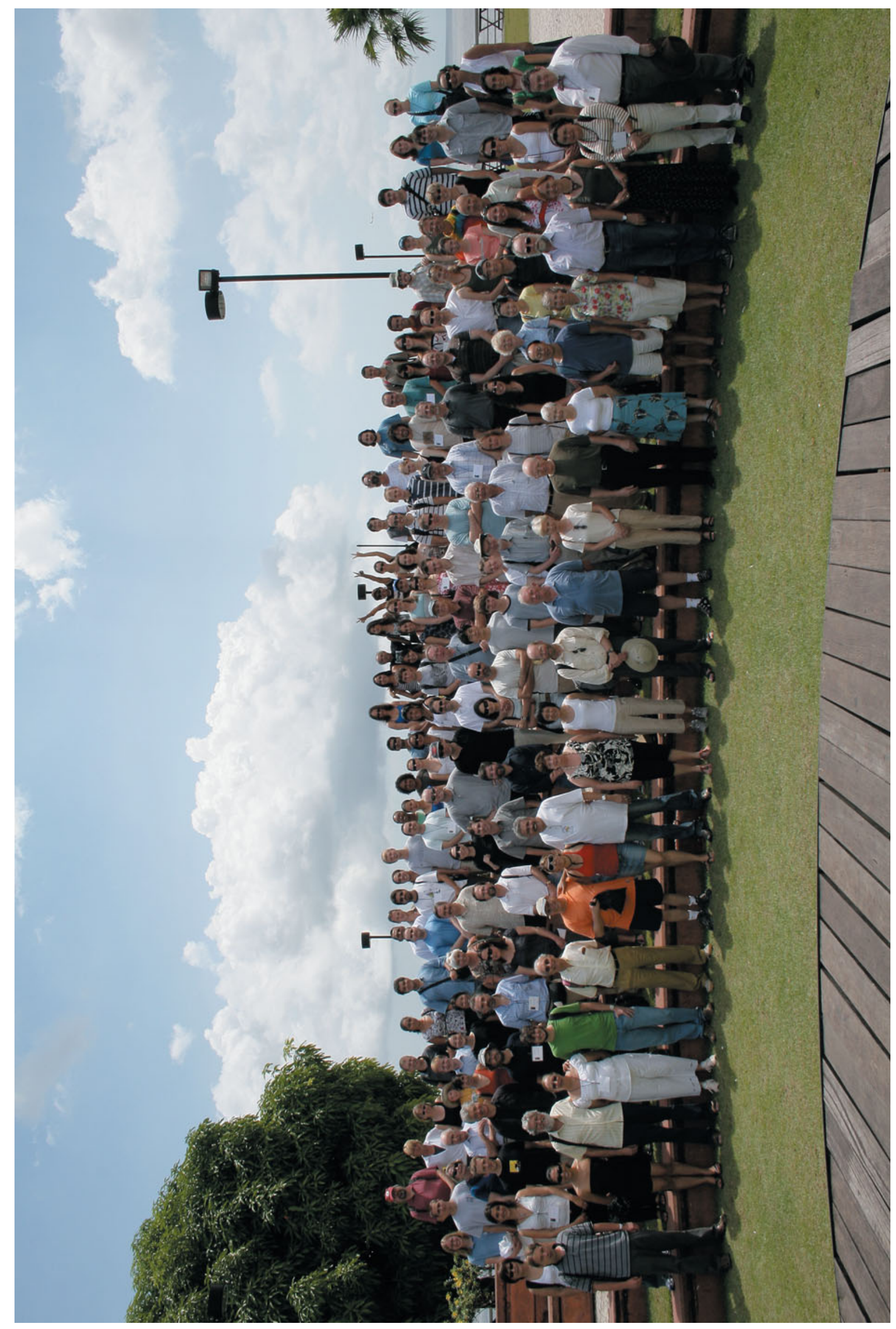

